\title{
A Real-Time PCR Assay for Early Detection of Eastern Filbert Blight
}

\author{
Thomas J. Molnar, Emily Walsh, and John M. Capik, Department of Plant Biology and Pathology, Rutgers University, New Bruns- \\ wick, NJ 08901; Vidyasagar Sathuvalli, Department of Horticulture, Oregon State University, Corvallis 97331-7304 and Hermiston \\ Agricultural Research and Extension Center, Oregon State University, Hermiston 97838; Shawn A. Mehlenbacher, Department of \\ Horticulture, Oregon State University, Corvallis; Amy Y. Rossman, Systematic Mycology \& Microbiology Laboratory, United States \\ Department of Agriculture-Agricultural Research Service, Beltsville, MD 20705; and Ning Zhang, Department of Plant Biology and \\ Pathology and Department of Biochemistry and Microbiology, Rutgers University
}

\begin{abstract}
Molnar, T. J., Walsh, E., Capik, J. M., Sathuvalli, V., Mehlenbacher, S. A., Rossman, A. Y., and Zhang, N. 2013. A real-time PCR assay for early detection of eastern filbert blight. Plant Dis. 97:813-818.

Eastern filbert blight (EFB) is a devastating disease of European hazelnut, Corylus avellana, which causes economic losses in Oregon, where 99\% of the U.S. crop is produced. The causal fungus, Anisogramma anomala, is native to eastern North America, where it is found associated with the American hazelnut (C. americana). Although $C$. americana is tolerant, EFB causes cankers, branch dieback, and death of $C$. avellana. Detection and identification of $A$. anomala is time consuming using conventional methods because the fungus can only be cultured from sporulating perithecia and the disease symptoms and signs only show 12 to 16 months after infection. In this study, a TaqMan

real-time polymerase chain reaction (PCR) assay based on a ribosomal DNA internal transcribed spacer was developed for A. anomala. The assay was validated with multiple isolates of $A$. anomala, closely related species, common environmental microorganisms, and over 100 C. avellana samples. The real-time PCR assay detected as low as 0.12 $\mathrm{pg}$ of A. anomala genomic DNA, and positively diagnosed EFB on $82 \%$ of asymptomatic plants as early as 15 weeks from infection. The real-time PCR assay is more sensitive and faster than traditional diagnostic methods. It can facilitate hazelnut breeding and disease management by early and accurate diagnosis of EFB.
\end{abstract}

Eastern filbert blight (EFB) is caused by the fungus Anisogramma anomala (Peck) E. Müll. This pathogen is an obligate, biotrophic ascomycete in the order Diaporthales known to infect only species of Corylus L. (filbert or hazelnut) $(12,16)$. It is native to a wide swath of North America east of the Rocky Mountains, where it occurs on the wild American hazelnut, Corylus americana Marshall. Although A. anomala causes only minor damage to $C$. americana $(4,13,51)$, it causes severe perennial cankers, branch die-back, and eventual death of nearly all cultivars of the commercially important European hazelnut, C. avellana L. (16,39). EFB is considered to be the primary limiting factor of European hazelnut production in eastern North America (50). The pathogen was inadvertently introduced into southwestern Washington in the 1960s (11) and devastated commercial hazelnut orchards because control measures were lacking at the time (14). It is now widespread across the Willamette Valley of Oregon, where $99 \%$ of the U.S. hazelnut crop is produced $(24,38,40,41)$. Diligent scouting for cankers, extensive pruning, and copious fungicide applications are necessary to continue production in the presence of the fungus (15). Due to the expense of these measures and the fact that hazelnut was traditionally a low-input crop, the development of EFBresistant cultivars was recognized as a more cost-effective, longterm management solution $(18,19,50)$. Breeding for resistance to $A$. anomala is now a major objective of hazelnut breeding programs in the United States $(23,32)$. Over the past 30 years, a number of sources of genetic resistance to the fungus have been identified in C. avellana as well as other Corylus spp. $(5,6,8,21,34,43,44)$. The earliest discovered $C$. avellana source was a simply inherited resistance $(R)$ gene from 'Gasaway' hazelnut, an obsolete pollinizer found to be resistant in $1975(3,29)$. Gasaway has been used extensively in hazelnut breeding at Oregon State University

Corresponding author: N. Zhang, E-mail: zhang @ aesop.rutgers.edu

Accepted for publication 11 January 2013.

http://dx.doi.org/10.1094/PDIS-11-12-1041-RE

(C) 2013 The American Phytopathological Society
(OSU), Corvallis. It is the source of resistance in 'Santiam', 'Yamhill', and 'Jefferson', the first EFB-resistant cultivars released for the Oregon industry that produce high yields of commercial-quality nuts $(25,27,28)$.

EFB resistance breeding is complicated by the lifecycle of the strictly sexual $A$. anomala, which includes a symptomless latent period spanning the entire first year of infection. Infection occurs in the spring during extended periods of rain when ascospores, spread by wind-driven rain and splash dispersal, directly penetrate young shoot tissues. It is only after the host plant cycles through a period of chilling and dormancy that the characteristic cankers erupt in the bark of stems, lining them with 2- to 4-by-2-mm, elliptical stromata visible by late summer (approximately 16 months after infection). Under field conditions, infected $C$. avellana typically die within 4 to 8 years of exposure (16).

The fungus is generally identified based on its morphological characteristics (i.e., cankers lined with conspicuous stromata or two-celled, ellipsoid, hyaline ascospores). During its latent phase, where the host plant shows no external symptoms, microscopic sectioning and staining is possible to identify fungal hyphae colonizing cells of the vascular cambium, phloem, and primary xylem $(7,48)$; however, this is not a definitive assay. In culture, which is possible only from the germination of excised ascospores, the fungus requires a medium with an adsorbent such as bovine serum albumin or activated charcoal (48). It grows very slowly, 2 to $3 \mathrm{~mm}$ in diameter at 6 weeks, typical of biotrophic fungi, with no sporulation or distinct morphological attributes. An enzyme-linked immunosorbent assay (ELISA) was developed that allows detection in infected stems at 3 to 5 months after inoculation (7). However, this antibody is currently not available.

A greenhouse inoculation method was developed to screen Corylus germplasm and breeding progeny for their response to the fungus. The protocol requires that plants be inoculated in the spring in a humidity chamber, then overwintered to fulfill their dormancy requirement. Susceptible plants develop stem cankers in late summer the following year-approximately 16 months after infection (17,37). Molnar et al. (30) developed an accelerated greenhouse inoculation method, reducing this timeline to around 9 months. To further improve efficiency in the hazelnut breeding 
program, breeders at OSU developed a marker-assisted selection (MAS) protocol to rapidly identify plants carrying specific resistant alleles at a very young age $(5,26,45,46)$. Although its routine use in the OSU breeding program has proven to be both effective and efficient, MAS takes years to develop and is only useful within breeding families segregating for known $R$ genes.

Real-time, or quantitative, polymerase chain reaction (real-time PCR) represents a highly sensitive and specific technique for the detection and quantification of nucleic acids (49). This method has been used for quantitative gene expression analysis, genotyping, and drug target validation, as well as pathogen detection (22). It offers a culture-independent, fast, and accurate method for the detection of microbial pathogens from soil, water, and host organisms. The interest in the real-time PCR technique in pathogen detection has increased exponentially in the past decade $(22,35)$. On 25 September 2012, a search in Web of Science using keywords "real-time PCR" and "pathogen detection" yielded 1,933 papers, among which 1,320 were published in the past 5 years.

The objective of this study was to develop a sensitive, culture-independent assay for early detection of $A$. anomala directly from hazelnut tissue using the TaqMan real-time PCR technique. We report here the development of the assay and demonstrate its application in the detection of the pathogen for hazelnut breeding and research.

\section{Materials and Methods}

Fungal isolates. In total, 27 fungal and oomycete isolates belonging to 14 species, including 12 isolates of $A$. anomala and 15 isolates of other species that are either closely related to the genus Anisogramma or common inhabitants of the environment, were used to test the specificity of the real-time PCR assay (Table 1). For A. anomala, infected branches showing stromata, previously stored at $-20^{\circ} \mathrm{C}$ in polyethylene bags, were thawed and then cut into $5-\mathrm{cm}$ sections. They were surface sterilized by soaking in $0.525 \%$ sodium hypochlorite for $3 \mathrm{~min}$, followed by sterile $\mathrm{H}_{2} \mathrm{O}$ for $1 \mathrm{~min}$, then $70 \%$ ethanol for $30 \mathrm{~s}$. Stems were then soaked in sterile $\mathrm{H}_{2} \mathrm{O}$ for $30 \mathrm{~min}$ to hydrate the stromata. The tops of the stromata were removed with a razor blade to expose the necks of the perithecia to reveal the inner, white-colored, viscous matrix that contains the ascospores. The matrix was picked up by a fine needle and collected in sterile $\mathrm{H}_{2} \mathrm{O}$ containing rifampicin at $10 \mathrm{ppm}$ and streptomycin at $100 \mathrm{ppm}$ and was vortexed for $1 \mathrm{~min}$ to release individual ascospores. The spore suspension was then diluted to $1.0 \times 10^{5}$ spores $/ \mathrm{ml}$ and $0.5 \mathrm{ml}$ was applied to petri plates containing Murashige and Skoog media amended with activated charcoal at $0.25 \mathrm{~g} / \mathrm{liter}$ and rifampicin at $10 \mathrm{mg} / \mathrm{liter}$ and overlaid with a cellophane membrane sheet. Cultures were grown in the absence of light for 8 weeks at $25^{\circ} \mathrm{C}$ (48). Mycelium was then harvested and ground with a mortar and pestle to a fine powder in liquid nitrogen. Other fungal and oomycete species were grown on a cellophane membrane sheet laid on full-strength potato dextrose agar (Difco Laboratories) at room temperature for 2 weeks before DNA extractions.

DNA extraction, PCR, and sequencing. For A. anomala, total genomic DNA was extracted using a standard phenol/chloroform protocol, as described by Crouch et al. (9). For other species, genomic DNA was extracted from 5 to $10 \mathrm{mg}$ of fresh mycelium from the microbial isolates (Table 1) or 30 to $40 \mathrm{mg}$ of the fresh plant samples (Table 2) using the DNeasy Plant Mini Kit (Qiagen) following the manufacturer's protocols. Plant samples were first

Table 1. List of fungal species, isolate number, and characteristics used to develop and evaluate the real-time polymerase chain reaction (PCR) method for Anisogramma anomala ${ }^{\mathrm{a}}$

\begin{tabular}{|c|c|c|c|c|c|c|}
\hline Species & Isolate $^{b}$ & Host & Location $^{c}$ & Year $^{d}$ & Collector $^{\mathrm{e}}$ & $\begin{array}{c}\text { Mean Ct } \\
(\text { SD })^{\mathbf{f}}\end{array}$ \\
\hline A. anomala & ADL-A4 & Corylus avellana & Rutgers Adelphia & 2003 & TM & $17.4(0.1)$ \\
\hline A. anomala & ADL-B1 & C. avellana & Rutgers Adelphia & 2003 & TM & $23.0(0.6)$ \\
\hline A. anomala & ARN1 & C. avellana & Arnold Arboretum, Boston & 2003 & $\mathrm{TM}$ & $21.9(0.4)$ \\
\hline A. anomala & CC-H1 & C. avellana & Rutgers Cook Campus & 2003 & $\mathrm{TM}$ & $20.4(0.8)$ \\
\hline A. anomala & CER3 & C. avellana $\times$ C. americana & Hazelnut Hill Farm & 2003 & $\mathrm{RC}$ & $17.1(0.0)$ \\
\hline A. anomala & CHAN2 & C. avellana & Chanticleer Pleasure Gardens & 2004 & TM & $17.5(0.2)$ \\
\hline A. anomala & CR-D1 & C. avellana & Rutgers Fruit Research & 2003 & TM & $31.7(5.6)$ \\
\hline A. anomala & HF2-A5 & C. avellana & Rutgers Farm 2 & 2003 & TM & $22.6(0.4)$ \\
\hline A. anomala & HF2-A8 & C. avellana & Rutgers Farm 2 & 2003 & $\mathrm{TM}$ & $18.9(0.1)$ \\
\hline A. anomala & HF2-B1 & C. avellana & Rutgers Farm 2 & 2003 & $\mathrm{TM}$ & $20.5(0.2)$ \\
\hline A. anomala & $\mathrm{HF} 2-\mathrm{C} 8$ & C. avellana & Rutgers Farm 2 & 2003 & $\mathrm{TM}$ & $30.8(7.3)$ \\
\hline A. anomala & OSU8 & C. avellana & OSU Smith Farm & 2003 & SM & $19.4(1.1)$ \\
\hline Alternaria alternata & 19 & Agrostis sp. & New Jersey & 2009 & $\mathrm{NZ}$ & - \\
\hline A. alternata & D30 (E1-8) & Cornus florida & New Jersey & 2009 & NZ & - \\
\hline Amphiporthe hranicensis & AR 3651=CBS119289 & Tilia platyphyllos & Austria & 2001 & AR & - \\
\hline Apiognomonia errabunda & AR2813=CBS109747 & Fagus sylvatica & Switzerland & $\ldots$ & AR & - \\
\hline Cladosporium tenuissimum & D27-4 & C. florida & Massachusetts & 2009 & RL & - \\
\hline Colletotrichum acutatum & D26-4 & C. florida & Massachusetts & 2009 & $\mathrm{NZ}$ & - \\
\hline Cryptosporella femoralis & AR3868=CBS121076 & Alnus rugosa & New York & $\ldots$ & AR & - \\
\hline Diaporthe eres & D34 (5P-3A) & C. florida & New Jersey & 2009 & NZ & - \\
\hline Discula destructiva & D33 (4P-3) & C. florida & New Jersey & 2009 & NZ & - \\
\hline D. destructiva & MD237-1 & C. florida & Massachusetts & 1990 & SCR & - \\
\hline Gnomonia gnomon & AR4071 & .. & $\ldots$ & $\ldots$ & AR & - \\
\hline Plagiostoma fraxini & AR2789=CBS109498 & Fraxinus pennsylvanica & Massachusetts & $\ldots$ & AR & - \\
\hline Pleuroceras pleurostylum & CBS906.79 & Salix lapponum & Sweden & $\ldots$ & AR & - \\
\hline Pythium sp. & D36 (7E-1) & Cornus florida & New Jersey & 2009 & NZ & - \\
\hline Waite a circinata & $1-1$ & Poa апnиа & New Jersey & 2009 & $\mathrm{NZ}$ & - \\
\hline
\end{tabular}

a Symbol - = undetected.

b Isolate numbers. CBS = Centraalbureau voor Schimmelcultures, Utrecht, The Netherlands.

${ }^{\mathrm{c}}$ Rutgers Adelphia = Rutgers Adelphia Research and Extension Farm, Adelphia, NJ; Rutgers Cook Campus = Rutgers University, Cook Campus, New Brunswick, NJ; Hazelnut Hill Farm, Wykoff, MN; Chanticleer Pleasure Gardens, Wayne, PA; Rutgers Fruit Research = Rutgers Fruit Research and Extension Center, Cream Ridge, NJ; Rutgers Farm 2 = Rutgers Horticultural Research Farm 2, New Brunswick, NJ; and OSU Smith Farm = Oregon State University Smith Horticultural Research Farm, Corvallis, OR.

d Year of collection.

e AR = Amy Rossman, NZ = Ning Zhang, RC = Roy Cerling, RL = Rebecca Loncosky, SCR = Scott Redlin, SM, Shawn Mehlenbacher, and TM = Thomas Molnar.

${ }^{\mathrm{f}}$ Real-time PCR threshold cycle (Ct) values and standard deviation (SD). 
cut into 1-mm strips and homogenized using the Qiagen TissueLyser for 10 to $15 \mathrm{~min}$ at 20 oscillations/second, adding both 7-mm stainless steel beads and sterile sand. Extracted DNA was measured on a NanoVue (GE Healthcare) to determine concentration and purity. For the microbial isolates, the internal transcribed spacer (ITS) region was amplified with primers ITS4 and ITS5 (52). PCR was carried out in a 2720 Thermo Cycler (Applied Biosystems) with 1 unit of AmpliTaq DNA Polymerase (Applied Biosystems), $1 \times$ buffer II (Applied Biosystems), $2.5 \mathrm{mM} \mathrm{MgCl}$, $0.8 \mathrm{mM}$ dNTPs, $0.2 \mu \mathrm{M}$ each primer, and $5 \mathrm{ng}$ of template DNA in a $50-\mu \mathrm{l}$ reaction. Cycling conditions consisted of an initial $5 \mathrm{~min}$ at $95^{\circ} \mathrm{C} ; 35$ cycles of $1 \mathrm{~min}$ at $95^{\circ} \mathrm{C}, 1 \mathrm{~min}$ at $56^{\circ} \mathrm{C}$, and $1 \mathrm{~min}$ at $72^{\circ} \mathrm{C}$; and a final step of $10 \mathrm{~min}$ at $72^{\circ} \mathrm{C}$. PCR products were purified using QIAquick PCR purification kit (Qiagen) following the manufacturer's protocol. The purified amplicons were sequenced with the primers ITS4 and ITS5 and the sequence data were used to confirm species identification.

Primer and probe design. The ITS sequences of $A$. anomala and other microbial species listed in Table 1 were aligned using the CLUSTAL X program (50). Based on the alignment, A. anomalaspecific primers and a probe were designed and evaluated with Primer3 (42) and Oligonucleotide Properties Calculator (20,42) programs. The designed primers for A. anomala were AaITSF1, 5' TTTGTGAATCTTCTCCGTTGC $3^{\prime}$ and AaITSR1, 5' TCATTT CTGTCAAAGGCTCAGA 3'. The TaqMan probe was AaITSprobe1, 5' CGGCCCCATAAACACTGCTCCTGTT 3', labeled at the $5^{\prime}$ end with the fluorophore FAM and at the $3^{\prime}$ end with the Iowa Black FQ quencher. The PCR product size was $135 \mathrm{bp}$. The primers and probe were synthesized by Integrated DNA Technologies (http://www.idtdna.com).

Real-time PCR assay conditions. Real-time PCR reactions were carried out with the StepOnePlus real-time PCR system (Applied Biosystems) using the program of an initial 3 min at $95^{\circ} \mathrm{C}$ followed by 45 cycles of $15 \mathrm{~s}$ at $95^{\circ} \mathrm{C}$ and $40 \mathrm{~s}$ at $60^{\circ} \mathrm{C}$. Amplifications were conducted in a total volume of $15 \mu$, which consisted of $7.5 \mu \mathrm{l}$ of iTaq Supermix with ROX (Bio-Rad), $250 \mathrm{nM}$ probe, 500 $\mathrm{nM}$ each primer, and $4 \mu \mathrm{l}$ of template DNA. For plant samples and non-target fungal isolates, the DNA concentration used was 2 $\mathrm{ng} / \mu \mathrm{l}$. For the A. anomala cultures, the DNA concentration was 0.5 $\mathrm{pg} / \mu \mathrm{l}$ to $1.75 \mathrm{ng} / \mu \mathrm{l}$. Each sample was tested in triplicate. A threshold cycle $(\mathrm{Ct})$ value less than 35 was determined as positive detection of A. anomala.

Validation of real-time PCR assay as applied in a breeding program. Plant material. A full-sibling progeny of hazelnut seedlings, designated 10007, derived from a controlled cross between an EFB-susceptible parent (OSU 1186.129) and an EFB-resistant parent (OSU 880.081) containing the Gasaway $R$ gene, was inoculated with $A$. anomala in the greenhouse. The controlled cross was made at OSU following methods described by Mehlenbacher (23). Based on earlier work with the Gasaway $R$ gene $(26,29)$, the resulting plants were expected to segregate in a ratio of one resistant to one susceptible. Seed were harvested in September 2010 and were provided moist chilling at $4^{\circ} \mathrm{C}$ from October 2011 to March 2012. Seed were then germinated in a peat-based planting medium (Promix BX; Premier Horticulture) in a greenhouse maintained at 24 and $18^{\circ} \mathrm{C}$ (day and night, respectively) with 16-h day length. After 5 weeks, 125 seedlings were transplanted into 3.7-liter containers using the same planting medium. Each seedling was top-dressed with $5 \mathrm{~g}$ of slow-release fertilizer (Osmocote Plus 15N-3.9P-10K with micronutrients, 5- to 6-month release; The Scotts Co.) and watered as needed over the course of the experiment.

Inoculations. Seedlings were placed in a humidity chamber constructed of a polyvinyl chloride tube frame ( 4.88 by 1.83 by 0.85 $\mathrm{m})$ set on top of a greenhouse bench and completely covered with polyethylene sheeting. Two humidifiers (Trion Herrmidifier 707 Series; Herrmidifier Co.) were placed in the chamber and run as needed to maintain relative air humidity near $100 \%$ for the inoculation period. On each plant, a small amount of yellow wound sealant (Doc Farwell's Grafting Seal; Farwell Products) was applied to the stem directly below the fourth node from the most apical point of the stem. This was done to indicate the approximate region of the stem where inoculation would have occurred (i.e., four nodes above the wound sealant) to specify the desired sampling area for real-time PCR analysis. Ascospore suspensions were prepared by dissecting whole stromata from infected stem pieces. Stems were collected in January 2011 from naturally infected plants growing at

Table 2. Comparison of real-time polymerase chain reaction (PCR) results and symptoms of eastern filbert blight in hazelnut (Corylus avellana) tissue

\begin{tabular}{|c|c|c|c|c|c|}
\hline \multirow[b]{2}{*}{ Sample ${ }^{b}$} & \multicolumn{2}{|c|}{ Symptoms $^{\mathrm{a}}$} & \multirow[b]{2}{*}{ Location $^{c}$} & \multirow[b]{2}{*}{ Mean Ct (SD) $)^{d}$} & \multirow[b]{2}{*}{ Detection (\%) } \\
\hline & When sampling & Week 55 & & & \\
\hline 76 & No symptom & NA & Rutgers Farm & - & NA \\
\hline 131 & Cankers & NA & Rutgers Farm & $22.9(0.2)$ & NA \\
\hline 132 & Cankers & NA & Rutgers Farm & $20.9(0.3)$ & NA \\
\hline 133 & Cankers & NA & Rutgers Farm & $30.9(0.2)$ & NA \\
\hline 135 & Cankers & NA & Rutgers Farm & $19.6(0.3)$ & NA \\
\hline 137 & Cankers & NA & Olson Tree Farm, Findley Lake, NY & $17.9(0.1)$ & NA \\
\hline 138 & Cankers & NA & Dawes Arboretum, Newark, OH & $16.3(0.1)$ & NA \\
\hline - Control & No symptoms & No symptoms & Noninoculated seedling & - & NA \\
\hline$R+(6$ week $) n=9$ & No symptoms & No symptoms & Progeny 10007 & NA & 0 \\
\hline$R+(10$ week $) n=10$ & No symptoms & No symptoms & Progeny 10007 & NA & 10 \\
\hline$R+(15$ week $) n=9$ & No symptoms & No symptoms & Progeny 10007 & NA & 0 \\
\hline$R+(20$ week $) n=9$ & No symptoms & No symptoms & Progeny 10007 & NA & 0 \\
\hline$R+(29$ week $) n=10$ & No symptoms & No symptoms & Progeny 10007 & NA & 0 \\
\hline$R+(37$ week $) n=10$ & No symptoms & No symptoms & Progeny 10007 & NA & 0 \\
\hline$R-(4$ week $) n=10$ & No symptoms & Cankers & Progeny 10007 & NA & 50 \\
\hline$R-(6$ week $) n=10$ & No symptoms & Cankers & Progeny 10007 & NA & 60 \\
\hline$R-(10$ week $) n=10$ & No symptoms & Cankers & Progeny 10007 & NA & 70 \\
\hline$R-(15$ week $) n=11$ & No symptoms & Cankers & Progeny 10007 & NA & 82 \\
\hline$R-(20$ week $) n=10$ & No symptoms & Cankers & Progeny 10007 & NA & 80 \\
\hline$R-$ (29week) $n=10$ & No symptoms & Cankers & Progeny 10007 & NA & 100 \\
\hline$R-(37$ week $) n=10$ & No symptoms & Cankers & Progeny 10007 & NA & 100 \\
\hline
\end{tabular}

${ }^{\text {a }}$ Symptoms when sampling and symptoms at week 55 after inoculation; NA = not applicable.

${ }^{\mathrm{b}}$ The first seven samples were collected from plants growing in the field naturally infected by Anisogramma anomala. Plants of progeny 10007, which were inoculated in the greenhouse with $A$. anomala and are segregating for the 'Gasaway' resistance $(R)$ gene, were sampled at 4, 6, 10, 15, 20, 29, and 37 weeks after inoculation. At each date, 9 to 11 individual plants were sampled from each type ( $R+$ and $R-)$.

${ }^{\mathrm{c}}$ Rutgers Farm $=$ Rutgers Vegetable Research and Extension Farm, North Brunswick, NJ.

${ }^{\mathrm{d}}$ Real-time PCR mean threshold cycle $(\mathrm{Ct})$ value and standard deviation (SD).

${ }^{\mathrm{e}}$ Percent plants that showed positive detection of A. anomala. Ct values lower than 35 were counted as + . Due to space limitation, individual $\mathrm{Ct}$ values are not listed. 
the Rutgers Vegetable Research and Extension Farm, North Brunswick, $\mathrm{NJ}$, and stored frozen at $-20^{\circ} \mathrm{C}$ in polyethylene bags to maintain their viability until needed. The stems were thawed and stromata were hydrated in distilled water, then crushed with a mortar and pestle to release the ascospores. The resulting suspension was filtered through two layers of cheesecloth and diluted to $1 \times 10^{6}$ ascospores $/ \mathrm{ml}$ in sterile distilled water (17). Immediately after preparation, the ascospore suspension was applied to the newly expanding shoot tips of each seedling by spraying them with a handheld pump sprayer until runoff. Plants were inoculated three times on the mornings of 2, 4, and 6 May 2011, and were removed from the humidity chamber on 9 May 2011. Following inoculations, seedlings were maintained in the greenhouse under optimal growing conditions until being moved outside under $40 \%$ shade cloth in August 2011. They were placed in an overwintering greenhouse (minimum temperature of 1 to $2^{\circ} \mathrm{C}$ ) in November 2011, to receive chilling. In April 2012, plants were moved back outside under shade to break dormancy under natural conditions and to induce canker development. In June 2012, all plants were scored for the incidence of EFB by visually examining stems for the presence of EFB cankers.

Plant genotyping. In May 2011, six to eight young leaves of each plant of progeny $10007(n=125)$ were collected and DNA extractions were completed following the protocol of Lunde et al. (21). DNA was then screened with the randomly amplified polymorphic DNA (RAPD) primers UBC $152_{800}$, UBC 268 ${ }_{580}$, and OP $\mathrm{AA}_{12850}(26)$ and sequence-characterized amplified region (SCAR) primer BE62 (47), routinely used by the OSU hazelnut breeding program to identify seedlings segregating for the Gasaway $R$ gene $(10,26)$. Amplification products were separated by electrophoresis on $2 \%$ agarose, stained with ethidium bromide, destained, visualized with a transilluminator, and then photographed. Amplification results were then used to separate the plants into two groups: plants that showed amplification of the Gasaway markers $(R+)(n=49)$ and those that did not $(R-)(n=67)$. If the results of the marker screening indicated recombination in the Gasaway resistance region, or if amplification was poor after a second run, those plants were excluded from the study $(n=10)$. Then, for each real-time PCR assay date (Table 2), approximately 10 different seedlings from each group $(R+$ and $R-$ ) were randomly selected for sampling. Twenty seedlings were sampled two or three times at different time points but the majority were sampled only once.

Plant material sampling. Stem areas around the third, fourth, and fifth nodes above the yellow wound sealant were sampled by using a scalpel to remove a 1 - to 1.5 -cm-length piece of tissue 1 to $2 \mathrm{~mm}$ deep, which comprises the bark and upper layer of the vascular tissue. In general, sections were removed on opposite sides of the stem to sample around its diameter. Only small, shallow samples were taken to reduce injury to the trees to promote

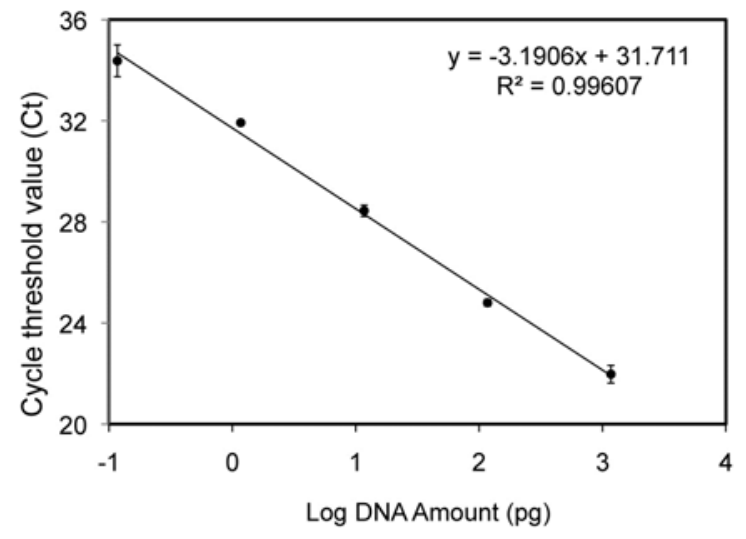

Fig. 1. Real-time polymerase chain reaction standard curve of the log of Anisogramma anomala input genomic DNA amount versus the corresponding cycle threshold (Ct) values. Standard deviations are labeled for each data point. Note: Some values of the standard deviation are very small and may be difficult to view. normal plant growth and the subsequent expression of typical EFB cankers on the susceptible individuals. The wounds were wrapped with Parafilm to aid in healing. Sampling occurred seven times starting at 4 weeks after inoculation. The sampling dates and numbers of plants included in each are shown in Table 2. Each time, stem sections were cut from approximately 10 different, randomly selected plants from each of the $R+$ and $R$ - groups. Collected samples were transported to the laboratory and processed within $24 \mathrm{~h}$ of collection. After sampling, plants were placed back with their respective groups and treated as described earlier. One healthy, noninoculated seedling plant was used as a control. At the conclusion of the experiment, the real-time PCR score, RAPD and SCAR marker scores, and incidence of EFB were compiled and compared for each seedling, with data summarized in Table 2.

\section{Results}

Standard curve, detection efficiency, and sensitivity. A fivepoint semi-log standard curve of $A$. anomala genomic DNA serial dilutions (0.12 pg to $1.12 \mathrm{ng}$ ) using isolate HF2-B1 showed a linear relationship between the $\mathrm{Ct}$ value and the log template DNA amount (Fig. 1). The slope of the standard curve was -3.1906 and the correlation coefficient $\left(R^{2}\right)$ was 0.996 . The real-time PCR efficiency was $105.8 \%$ based on the formula Efficiency $=\left(10^{(-1 / \text { slope })}-1\right)$ $\times 100 \%$. The assay can detect as low as $0.12 \mathrm{pg}$ of $A$. anomala genomic DNA.

Detection specificity. The designed assay was tested with genomic DNA of 12 different $A$. anomala isolates and 13 reference species (Table 1). All A. anomala isolates produced the expected 135-bp amplicons, the identities of which were confirmed by sequencing. Low $\mathrm{Ct}$ values (17.1 to 31.7 ) were obtained consistently for all of the tested A. anomala isolates originating from various locations, host plants, and collection dates. Therefore, the positive detection was unambiguous and inclusive. No amplification was detected from the reference species (Table 1).

Direct real-time PCR detection from plant samples. All six field-collected hazelnut samples that showed cankers on branches (Table 2, samples 131, 132, 133, 135, 137, and 138) yielded positive real-time PCR detection, with Ct values of 16.3 to 30.9 (Table 2). Sample 76, which showed no canker symptoms, had negative detection results. For the $R+$ greenhouse plants, the positive detection percentage was $22 \%$ at 4 weeks after inoculation and decreased afterward. For the $R$ - plants, the positive detection percentage was $50 \%$ at 4 weeks, ultimately reaching $100 \%$ at 29 weeks and later (Fig. 2). In June 2012, approximately 58 weeks after inoculation, EFB cankers were clearly visualized on all $R$ - plants included in the study, with no cankers found on the $R+$ plants, fitting the MAS genotype scoring $100 \%$ (data not shown), as well as the real-time PCR results on plants sampled at 29 weeks from inoculation onward.

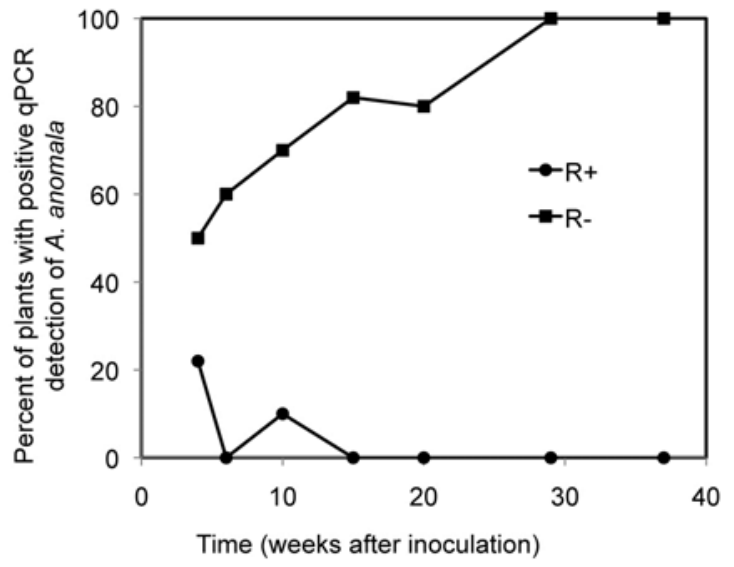

Fig. 2. Percentage of sampled hazelnut plants that were detected positive with realtime polymerase chain reaction for Anisogramma anomala at each sampling date. $R+$ and $R$ - plants were calculated separately. 


\section{Discussion}

To support disease diagnostic measures and facilitate hazelnut breeding efforts, we developed a real-time PCR assay to detect $A$. anomala directly from host plant tissue. In this study, we chose TaqMan chemistry because of its higher detection specificity (35).

Genetic variability within $A$. anomala is very low (2). No sequence diversity was found for over 100 isolates sampled in the ITS region, the target sequence for our real-time PCR assay (2). According to the BLAST results, the closest ITS sequence to $A$. anomala is from Cryptosporella jaklitschii L.C. Mejia (GenBank accession GU826089), which has an 88\% sequence similarity. This species belongs to the family Gnomoniaceae, Diaporthales. De Silva et al. (12) showed that the genus Anisogramma, although sister to the families Gnomoniaceae and Melanconidaceae, has no close relatives and falls outside of these two families. Because of the low genetic diversity and high dissimilarity with related species, the A. anomala specific real-time PCR primer design was relatively easy. More challenging molecular detection assays are caused by high population diversity of the target species and identical or high similarity between target species and non-targets. For example, Magnaporthe poae Landsch. \& N. Jacks., the summer patch pathogen of turfgrass, shares ITS sequences with $M$. rhizophila D.B. Scott \& Deacon, a wheat-associated pathogen; thus, the two species are indistinguishable in an ITS-based realtime PCR assay (53).

The real-time PCR assay for A. anomala developed in this study is highly specific. All $12 \mathrm{~A}$. anomala isolates from various sources yielded unambiguous positive detection. The other diaporthalean species that are closely related to A. anomala tested in this study produced no fluorescence signal and were scored negative. The assay is also very sensitive. It can detect as low as $0.12 \mathrm{pg}$ of $A$. anomala genomic DNA. At week 6 after inoculation, the assay detection results were $79 \%$ accurate (i.e., for 15 of 19 plants sampled, the real-time PCR assay data matched the disease symptoms expressed the next summer). The detection accuracy increased to $90 \%$ at week 15 and ultimately reached $100 \%$ at week 29 . The ELISA assay for EFB was reported to have $98 \%$ detection accuracy for field samples at 20 weeks after inoculation (7). However, the ELISA assay was found to have cross-reaction with Cladosporium spp., while the real-time PCR assay detected $A$. anomala exclusively. Although shown here to be only approximately $80 \%$ accurate, the real-time PCR assay can be used as early as 6 weeks after inoculation. This may be useful in scenarios where early detection is considered more important than accuracy, such as when screening large numbers of breeding progeny for susceptibility to A. anomala.

Found only in North America, A. anomala is a European and Mediterranean Plant Protection Organization A1 registered quarantine pest (1). Strict regulations on the transport of Corylus plant material out of North America are currently intact and must be maintained, because an introduction of A. anomala into Europe or other commercial growing regions could be devastating to hazelnut production, as well as to natural areas where Corylus avellana is a forest component. Further, some eastern U.S. isolates have been shown to be able to infect sources of resistance in use in Oregon, including the $R$ gene from Gasaway $(31,33)$. Thus, it is critical that additional isolates of the fungus are not transported into the western United States. Based on this potentiality, a ban on importing Corylus spp. from the eastern United States into Oregon is currently in effect (36). The long, symptomless latent phase of $A$. anomala, sometimes lasting up to 24 months (33), makes preventing future introductions of the disease organism a challenge. A complete ban on the movement of Corylus plant material out of the United States, while possible, is unlikely because new, high-yielding cultivars developed in the United States are highly beneficial to the hazelnut industry in Europe and other growing regions, where breeding programs are lacking. The real-time PCR assay developed here, which can detect minute quantities of the fungus during its latent phase, can provide an accurate and efficient diagnostic support tool to help prevent the spread of EFB.
Developing and validating the real-time PCR primers for $A$. anomala was the focus of this study and should be considered only a first step in developing this assay as an applied quarantine inspection tool. In our study, we used the real-time PCR assay as a tool to screen plants very early after infection for the presence of A. anomala in an applied breeding setting. Very small stem samples were removed from the inoculated trees to aid healing and promote normal growth after sampling. This approach was taken so that typical cankers were more likely to develop, which were necessary to later validate the real-time PCR results. We also wanted to demonstrate the ability to assess the plants with little set back in growth, which is important to a breeding program where destructive sampling would not be an option. However, the small stem samples collected in our study could have been the reason for the lack of detection (escapes) in some susceptible plants from the earlier sampling dates. In terms of using this highly sensitive assay as a quarantine inspection tool, where destructive sampling would be warranted, it is proposed that one could harvest a number of larger stem pieces (full-diameter stem samples, not just thin bark slivers), grind them individually, and then take subsamples of each and thoroughly mix them for batch DNA extraction and real-time PCR assay. When evaluating the batches of samples, any presence of the fungus would raise a red flag. Those trees from within the particular batch found to have a presence of $A$. anomala could then be sampled individually to identify the infected plant. This proposed approach would need to be validated in a future experiment that examines how many plants one could include in a batch, and so on, and what size of a stem sample is necessary to consistently reduce escapes from detection.

Based on results from this study, the real-time PCR assay may hold significant value in breeding for resistance to EFB. Its use can greatly expedite the screening of germplasm collections and breeding progeny for their susceptibility to infection by A. anomala. In our study, the fungus could be detected in a high percentage of the susceptible plants by 15 weeks after inoculation, with all identified by 29 weeks. For a breeding program where seed are typically germinated in the spring and trees planted in the fall, the real-time PCR analysis would allow for the discarding of susceptible plants in mid- to late summer prior to field planting or overwintering. Only those plants showing no signs of A. anomala would be retained for further evaluations. This would result in substantial savings of labor, supplies, and field or greenhouse space.

Unlike the use of MAS, the real-time PCR assay is independent of breeding line (i.e., specific genes for resistance) and provides a direct measure of the plant's response to exposure to the pathogen. However, the assay is dependent on successful inoculation of the plant material, because escapes would clearly reduce its usefulness. It may also be limited to screening progeny segregating for major genes for resistance because plants expressing tolerance, such as by reduced number of cankers or smaller-sized cankers, would be subjected to some colonization by A. anomala and would be designated as susceptible in the assay. However, through further study, it might be possible to identify plants expressing tolerance to EFB by correlating phenotype with $\mathrm{Ct}$ values.

The real-time PCR assay also opens up the opportunity to study the progression of EFB within the host plant $(R+$ and $R-)$ as well as other host-pathogen interactions, including that of its native host, $C$. americana, where it is possible that $A$. anomala acts more as an endophyte.

\section{Acknowledgments}

This work was funded by the New Jersey Agricultural Experiment Station, the Rutgers Center for Turfgrass Science, Hatch funds provided by the United Stated Department of Agriculture (USDA)-NIFA, and the USDA-NIFA Specialty Crops Research Initiative Competitive Grant 2009-51181-06028. We thank the anonymous reviewers whose comments helped to improve this article.

\section{Literature Cited}

1. Anonymous. 2012. EPPO A1 List of pests recommended for regulation as quarantine pests. http://www.eppo.int/QUARANTINE/listA1.htm

2. Baxer, S. N., Crouch, J, Funk, C. R., Molnar, T. J., and Hillman, B. I. 2007 Genetic variability of eastern filbert blight pathogen, Anisogramma 
anomala. (Abstr.) Phytopathology 97:S8.

3. Cameron, H. R. 1976. Eastern filbert blight established in the Pacific Northwest. Plant Dis. Rep. 60:737-740.

4. Capik, J. M., and Molnar, T. J. 2012. Assessment of host (Corylus sp.) resistance to eastern filbert blight in New Jersey. J. Am. Soc. Hortic. Sci. 137:157-172.

5. Chen, H., Mehlenbacher, S. A., and Smith, D. C. 2005. AFLP markers linked to eastern filbert blight resistance from OSU 408.040 hazelnut. J. Am. Soc. Hortic. Sci. 130:412-417.

6. Chen, H., Mehlenbacher, S. A., and Smith, D. C. 2007. Hazelnut accessions provide new sources of resistance to eastern filbert blight. HortScience 42:466-469.

7. Coyne, C. J., Mehlenbacher, S. M., Hampton, R. O., Pinkerton, J. N., and Johnson, K. B. 1996. Use of ELISA to rapidly screen hazelnut for resistance to eastern filbert blight. Plant Dis. 80:1327-1330.

8. Coyne, C. J., Mehlenbacher, S. A., and Smith, D. C. 1998. Sources of resistance to eastern filbert blight. J. Am. Soc. Hortic. Sci. 124:253-257.

9. Crouch, J., Clarke, B. B., and Hillman, B. I. 2005. Phylogenetic relationships and fungicide sensitivities of Colletotrichum graminicola isolates from turfgrass in North America Int. Turfgrass Soc. Res. 10:186-195.

10. Davis, J. W., and Mehlenbacher, S. A. 1997. Identification of RAPD markers linked to eastern filbert blight resistance in hazelnut. Acta Hortic. 445:553-556.

11. Davison, A. D., and Davidson, R. M. 1973. Apioporthe and Monochaetia canker reported in western Washington. Plant Dis. Rep. 57:522-523.

12. De Silva, H., Castlebury, L. A., Green, S., and Stone, J. K. 2009. Characterisation and phylogenetic relationships of Anisogramma virgultorum and $A$. anomala in the Diaporthales (Ascomycota). Mycol. Res. 113:73-81.

13. Fuller, A. S. 1908. The Nut Culturist. Orange Judd, New York.

14. Gottwald, T. R., and Cameron, H. R. 1980. Disease increase and the dynamics of spread of canker caused by Anisogramma anomala in European filbert in the Pacific Northwest. Phytopathology 70:1087-1092.

15. Johnson, K. B., Mehlenbacher, S. A., Stone, J. K., and Pscheidt, J. W. 1996. Eastern filbert blight of European hazelnut: it's becoming a manageable disease. Plant Dis. 80:1308-1316.

16. Johnson, K. B., and Pinkerton, J. N. 2002. Eastern filbert blight. Pages 4446 in: Compendium of Nut Crop Diseases in Temperate Zones. B. L. Teviotdale, T. J. Michailides, and J. W. Pscheidt, eds. American Phytopathological Society, St. Paul, MN.

17. Johnson, K. B., Pinkerton, J. N., Gaudreault, S. M., and Stone, J. K. 1994. Infection of European hazelnut by Anisogramma anomala: site of infection and effect on host developmental stage. Phytopathology 84:1465-1470.

18. Julian, J. W., Seavert, C. F., and Olsen, J. L. 2008. Orchard economics: the costs and returns of establishing and producing hazelnuts in the Willamette Valley. Oreg. State Univ. Ext. Serv. Bull. EM 8748-E.

19. Julian, J., Seavert, C., and Olsen, J. L. 2009. An economic evaluation of the impact of eastern filbert blight resistant cultivars in Oregon, U.S.A. Acta Hortic. 845:725-732.

20. Kibbe, W. A. 2007. OligoCalc: an online oligonucleotide properties calculator, Nucleic Acids Res. 35 (Webserver Issue):May 25.

21. Lunde, C. F., Mehlenbacher, S. A., and Smith, D. C. 2000. Survey of hazelnut cultivars for response to eastern filbert blight inoculation. HortScience 35:729-731.

22. Mackay, I. 2007. Real-Time PCR in Microbiology: From Diagnosis to Characterization. Caister Academic Press, Australia

23. Mehlenbacher, S. A. 1994. Genetic improvement of the hazelnut. Acta Hortic. 351:23-38.

24. Mehlenbacher, S. A. 2005. The hazelnut situation in Oregon. Acta Hortic. 686:665-667.

25. Mehlenbacher, S. A., Azarenko, A. N., Smith, D. C., and McCluskey, R. L. 2007. 'Santiam' hazelnut. HortScience 42:715-717.

26. Mehlenbacher, S. A., Brown, R. N., Davis, J. W., Chen, H., Bassil, N. V., Smith, D. C., and Kubisiak, T. L. 2004. RAPD markers linked to eastern filbert blight resistance in Corylus avellana. Theor. Appl. Genet. 108:651-656

27. Mehlenbacher, S. A., Smith, D. C., and McCluskey, R. L. 2009. 'Yamhill' hazelnut. HortScience 44:845-847.

28. Mehlenbacher, S. A., Smith, D. C., and McCluskey, R. 2011. 'Jefferson' hazelnut. HortScience 46:662-664.

29. Mehlenbacher, S. A., Thompson, M. M., and Cameron, H. R. 1991. Occurrence and inheritance of immunity to eastern filbert blight in 'Gasaway' hazelnut. HortScience 26:410-411.
30. Molnar, T. J., Baxer, S. N., and Goffreda, J. C. 2005. Accelerated screening of hazelnut seedlings for resistance to eastern filbert blight. HortScience 40:1667-1669.

31. Molnar, T. J., Capik, J., Zhao, S., and Zhang, N. 2010. First report of eastern filbert blight on Corylus avellana 'Gasaway' and 'VR20-11' caused by Anisogramma anomala (Peck) E. Müller in New Jersey. Plant Dis. 94:1265.

32. Molnar, T. J., Goffreda, J. C., and Funk. C. R. 2005. Developing hazelnuts for the eastern United States. Acta Hortic. 68:609-617.

33. Molnar, T. J., Goffreda, J. C., and Funk, C. R. 2010. Survey of Corylus resistance to Anisogramma anomala from different geographic locations. HortScience 45:832-836.

34. Molnar, T. J., Mehlenbacher, S. A., Zaurov, D. E., and Goffreda, J. C. 2007. Survey of hazelnut germplasm from Russia and Crimea for response to eastern filbert blight. HortScience 42:51-56.

35. Okubara, P. A., Schroeder, K. L., and Paulitz, T. C. 2005. Real-time polymerase chain reaction: applications to studies on soilborne pathogens, Can. J. Plant Pathol. 27:300-313.

36. Oregon Summaries of Exterior Quarantines. 2012. Hazelnut nursery stock control area, 603-052-0825. State of Oregon Department of Agriculture Plant Division, Salem, Oregon. Online publication. www.nationalplant board.org/docs/summaries/oregon.doc

37. Osterbauer, N. K., Johnson, K. B., Mehlenbacher, S. A., and Sawyer, T. L. 1997. Analysis of resistance to eastern filbert blight in Corylus avellana. Plant Dis. 81:388-394.

38. Pinkerton, J. N., Johnson, K. B., Aylor, D. E., and Stone, J. K. 2001. Spatial and temporal increase of eastern filbert blight in European hazelnut orchards in the Pacific Northwest. Phytopathology 91:1214-1223.

39. Pinkerton, J. N., Johnson, K. B., Mehlenbacher, S. A., and Pscheidt, J. W 1993. Susceptibility of European hazelnut clones to eastern filbert blight Plant Dis. 77:261-266.

40. Pinkerton, J. N., Johnson, K. B., Theiling, K. M., and Griesbach, J. A. 1992 Distribution and characteristics of the eastern filbert blight epidemic in western Oregon. Plant Dis. 76:1179-1182.

41. Pscheidt, J., Grimaldi, P., and Penhallegon, R. 2012. Eastern filbert blight epidemic in the Pacific Northwest. Oregon State University. http://oregon state.edu/dept/botany/epp/EFB/location/map1.htm

42. Rozen, S., and Skaletsky, H. J. 2000. Primer3 on the WWW for general users and for biologist programmers. Pages 365-386 in: Bioinformatics Methods and Protocols: Methods in Molecular Biology. S. Krawetz and S. Misener, eds. Humana Press, Totowa, NJ.

43. Sathuvalli, V., Mehlenbacher, S. A., and Smith, D. C. 2009. New sources of eastern filbert blight and linked markers. Acta Hortic. 845:123-126.

44. Sathuvalli, V., Mehlenbacher, S. A., and Smith, D. C. 2010. Response of hazelnut accessions to greenhouse inoculation with Anisogramma anomala. HortScience 45:1116-1119.

45. Sathuvalli, V., Mehlenbacher, S. A., and Smith, D. C. 2011. DNA markers linked to eastern filbert blight resistance from a hazelnut selection from the Republic of Georgia. J. Am. Soc. Hortic. Sci. 136:350-357.

46. Sathuvalli, V. R., Chen, H. L., Mehlenbacher, S. A., and Smith, D. C. 2010. DNA markers linked to eastern filbert blight resistance in 'Ratoli' hazelnut. Tree Genet. Genomes 7:337-345.

47. Sathuvalli, V. R., and Mehlenbacher, S. A. 2010. Fine mapping of eastern filbert blight resistance in hazelnut with SCAR and SSCP markers developed from BAC end sequences. Acta Hortic. 859:395-400.

48. Stone, J. K., Pinkerton, J. N., and Johnson, K. B. 1994. Axenic culture of Anisogramma anomala: evidence for self-inhibition of ascospore germination and colony growth. Mycologia. 86:674-683.

49. Taylor, E., Bates, J., Kenyon, D., Maccaferri, M., and Thomas, J. 2001. Modern molecular methods for characterization and diagnosis of seedborne fungal pathogens. J. Phytopathol. 83:75-81.

50. Thompson, M. M., Lagerstedt, H. B., and Mehlenbacher. S. A. 1996. Hazelnuts. Pages 125-184 in: Fruit Breeding, Vol. 3. Nuts. J. Janick and J. N. Moore, eds. Wiley, New York.

51. Weschcke, C. 1954. Growing Nuts in the North. Webb, St. Paul, MN

52. White, T. J., Bruns, T., Lee, S., and Taylor, J. 1990. Amplification and direct sequencing of fungal ribosomal RNA genes for phylogenetics. Pages $315-$ 322 in: PCR Protocols: A Guide to Methods and Applications. M. A. Innis, D. H. Gelfand, J. J. Sninsky, and T. J. White, eds. Academic Press, San Diego, CA.

53. Zhao, S., Clarke, B. B., Shen, Q., Zhang, L., and Zhang, N. 2012. Development and application of a TaqMan real-time PCR assay for rapid detection of Magnaporthe poae. Mycologia 104:1250-1259. 